\title{
A Brief Review of Probiotic Use.
}

\section{C.K. MAITAI* AND D.M. KOKONYA}

Department of Pharmacology and Pharmacognosy, School of Pharmacy, College of Health Sciences, University of Nairobi, P.O. Box 19676-00202, Nairobi, Kenya.

\begin{abstract}
Probiotic therapy refers to use of live microorganisms to treat human pathological disorders such as lactose intolerance and antibiotic induced superinfections. The critical point to be consideted is whether such administered microorganisms can remain viable and multiply in the gastrointestinal tract given that their nutrient and environmental condition requirements are very exacting. In this brief review, the authors discuss the use of probiotics from a historical perspective and conclude that their use especially in form of traditional fermented food products can be justified the controversy notwithstanding.
\end{abstract}

Keywords: Probiotic, Lactobacillus

\section{Introduction}

Probiotics are live microorganisms which when administered in adequate amounts confer health benefits to the host [1]. They may be used as dietary supplements and in alternative medicine. Until recently, porbiotics have not been subjected to scrutiny to justify their safety and efficacy. This is now changing and many publications regarding their use in such conditions as lactose intolerance, colon cancer, hypertension, inflammation and antibioticiduced suprinfections are readily available.

Probiotic use is deeply rooted in cultural practices. The earliest documented reference to probiotics dates back to 1908 when the Russian Nobel Laureate Elie Metchnikoff attributed the good health and longevity of Bulgarian peasants to a lactobacillus in yoghurt which he named Bacillus bulgaricus [2]. In 1920, Rottenger demonstrated that $B$. bulgaricus could not survive in the human intestinal tract [3]. In 1930, Japanese scientist Minoru Shirota isolated Lactobacillus casei which was later used to make 'Yokult', the first probiotic drink, which is still in the market [4]. In the 1960s, the use of Lactobacillus acidophilus to ferment dairy products was popularised. In addition, other probiotic bacteria have been introduced. These include Bifidobacteria spp, Streptococcus thermophilus and Eubacteria spp.

\section{Mechanism of action of probiotics}

Probiotics act principally in the gastrointestinal tract. The site and mechanism of action is summarised in Figure 1. Furthermore, it is known that some probiotics may be pathogenic, releasing noxious substances such as aminotoxins. In one clinical trial, a probiotic cocktail increased death rate of patients with pancreatitis [5].

For probiotics to be effective, they must remain viable in the gastrointestinal tract. Viability of bacteria may be improved by the medium. For example, when administered in form of yoghurt, bacteria are protected from effects of low $\mathrm{pH}$ and bile salts. Several studies show favourable outcome with respect to efficacy and safety following administration of Lactobacillus acidophilus [6-7]. Apart from bacteria, yeasts (Saccharomyces species) have been used as probiotics. However, when used to make traditional alcoholic brews by fermentation of carbohydrates, the process is self-limiting as the microorganisms are killed when alcohol concentration is about $6 \%$. 


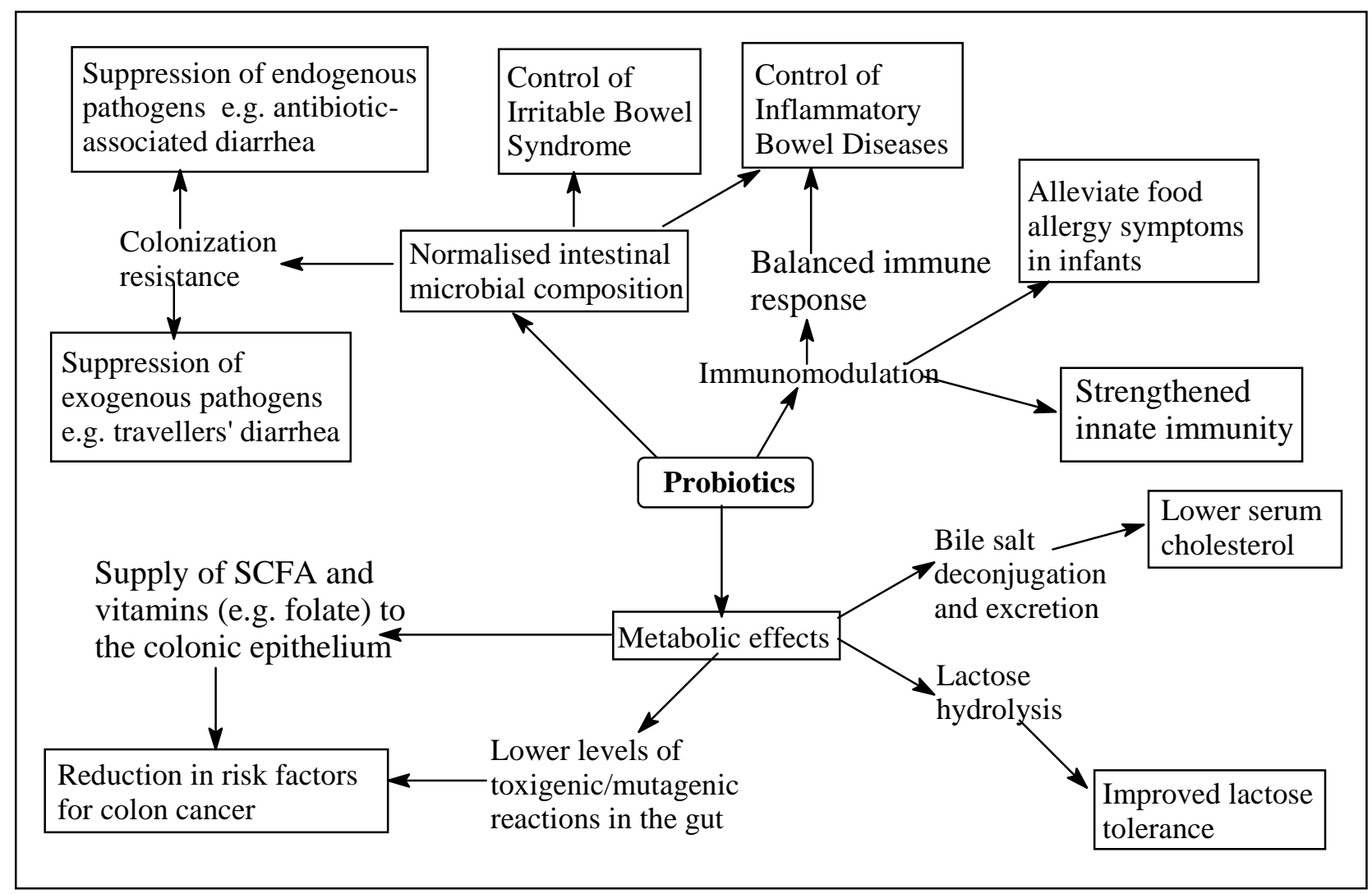

Figure 1: Possible machanism of action for probiotics.

\section{Traditional probiotic products}

Table 1 shows some probiotics of dairy origin used in different parts of the world wile Table 2 shows non-dairy traditional probiotic foods.

Table 1. Dairy traditional probiotic foods

\begin{tabular}{lll}
\hline Name & Type of food & Community \\
\hline Qula & Cheese & Tibet \\
Saler & Cheese & France \\
Dahir & Fermented milk & Indonesia \\
Nono & Fermented milk & Nigeria \\
Kefir & White cheese & Morocco \\
Mursik & Fermented milk & Kenya \\
Maziwa lala & Fermented milk & East Africa \\
\hline
\end{tabular}

\section{Probiotic pharmaceutical products}

Several probiotic pharmaceutical products are currently being marketed in different parts of the world. Examples of three products in the Kenyan Market are given below. These are used for gastointestinal infections.

Product 1: Trilac capsules/granules: Streptococcus faecalis (30 million cfu)

Clostridium butylicum (2 million cfu)

Bacillus mesenteericus (1 million cfu)

Lactobacillus sporogenes (50 million $\mathrm{cfu}$ )

Product 2: Enfor sachets

Saccharomyces boulardii (lyophilized) (hpl $250 \mathrm{mg}$ ) 
Product 3: Kalsis capsules

Calcium gluconate $(185 \mathrm{mg})$

Magnesium gluconate $(85 \mathrm{mg})$

Vitamin E (3 mg)

Selenium rich yeast $(16 \mathrm{mg})$

Lactobacillus (51 mg)

Table 2. Non-dairy traditional probiotic foods

\begin{tabular}{|c|c|c|}
\hline Name & Type of food & Community \\
\hline Sauerkraut & $\begin{array}{l}\text { Fermented } \\
\text { cabbage }\end{array}$ & Asia \\
\hline Kimchi & $\begin{array}{l}\text { Fermented } \\
\text { cabbage }\end{array}$ & Korea \\
\hline Ogi & Fermented maize & Nigeria \\
\hline Fufu & $\begin{array}{l}\text { Fermented } \\
\text { sorghum }\end{array}$ & Nigeria \\
\hline Tongwa & $\begin{array}{l}\text { Fermented } \\
\text { cassava }\end{array}$ & Tanzania \\
\hline Kocha & Fermented maize & Ethiopia \\
\hline $\begin{array}{l}\text { Sour } \\
\text { miffens }\end{array}$ & $\begin{array}{l}\text { Fermented black } \\
\text { tea }\end{array}$ & China \\
\hline Abagi & $\begin{array}{l}\text { Fermented } \\
\text { millet/sorghum } \\
\text { flour }\end{array}$ & Luo (Kenya) \\
\hline Anjera & $\begin{array}{l}\text { Fermented maize } \\
\text { flour }\end{array}$ & $\begin{array}{l}\text { Borana } \\
\text { (Kenya/Ethiopia) }\end{array}$ \\
\hline Tsimbare & $\begin{array}{l}\text { Fermented } \\
\text { millet/sorghum } \\
\text { flour }\end{array}$ & Luhya (Kenya) \\
\hline
\end{tabular}

\section{Research on probiotics}

The number of publications on probiotics (in brackets) over the past has been increasing as follows: 1950-1970 (4); 1971-1990 (11); 19911995 (58); 1996-2000 (65); and 2001-2005 (2663). There are no suitable animal models that can be used to study the efficacy of probiotics. In vitro tests give limited information and the use of probiotics will continue to be based on empirical evidence which in itself is not conclusive. The nutritional value of fermented products of dairy origin (Yoghurt, cheese, etc) justifies their use, the probiotic value notwithstanding.

\section{World market for probiotics}

The probiotic global market was estimated to be worth $\$ 14.9$ billion in 2007 and was expected to grow to $\$ 15.9$ billion in 2008. Most of the probiotics are marketed in form of food (e.g. yoghurt, fermented cheese) while a very small percentage is formulated as pharmaceutical preparations.

\section{REFERENCES}

[1] Joint FAO/WHO Expert Consultation Report on drafting Guidelines for Evaluation of Probiotics, London, April 20-May 1, 2002.

[2] E. Jonathan, Annual Review of Nutrition 22 (2002) 107, 138.

[3] H.A. Cheplin, L.F. Rettger, Proc. Nat. Acad. Sci. USA 6 (1920) 704-705.

[4] www.nutaingredient.com. Accessed August 25, 2008.

[5] M.G. Basselink, H.C. van Santvoort, E. Basken et al., Lancet 371 (2008) 651659.

[6] M. Beausoleil, N. Fortier, S. Guénette, A. L'ecuyer, M. Savoie, M. Franco, J. Lachaine and K. Weiss, Canadian J. Gastroenterol. 21 (2007) 732-736.

[7] A. Ljungh and T. Wadstrom (eds), Lactobacillus Molecular Biology: From Genomics to Probiotics, Ceister Academic Press, Norfolk, UK. 2009. 